(อ)

OPEN ACCESS

\title{
Untreated vertebral osteomyelitis extending to the mediastinum and lungs
}

Takuro Nakashima, ${ }^{1}$ Katsuyuki Sagishima, ${ }^{1}$ Hiroki Suenaga, ${ }^{2}$ Tatsuo Yamamoto ${ }^{1}$

'Department of Critical Care Medicine, Kumamoto University Hospital, Kumamoto, Japan ${ }^{2}$ Department of Radiology, Fukushima Medical University Hospital, Fukushima, Japan

\section{Correspondence to} Dr Takuro Nakashima; nakashima.takuro@gmail.com

Accepted 22 July 2020

\section{DESCRIPTION}

A 70-year-old man with untreated diabetes mellitus was admitted to our hospital presenting with fever and malaise. He had slipped and fallen on the street a month before.

A CT scan revealed a mediastinal abscess, right pneumothorax, and T2/3 spine destruction (figures 1-3.). MRI showed vertebral osteomyelitis, an epidural abscess, and an adjacent mediastinal abscess (figures 4-6). Blood culture was positive for Streptococcus intermedius. Vegetation was not detected by transthoracic echocardiography and repeated blood culture was negative after antimicrobial therapy. Endoscopy revealed that the oesophagus and trachea were intact.

The patient was transferred to our hospital 5 days later, where mediastinal abscess drainage and partial lung resection of the bilateral upper lobes were performed. Posterior spine fixation was performed 5 days after the first operation. Epidural abscess drainage was not performed, because we feared it

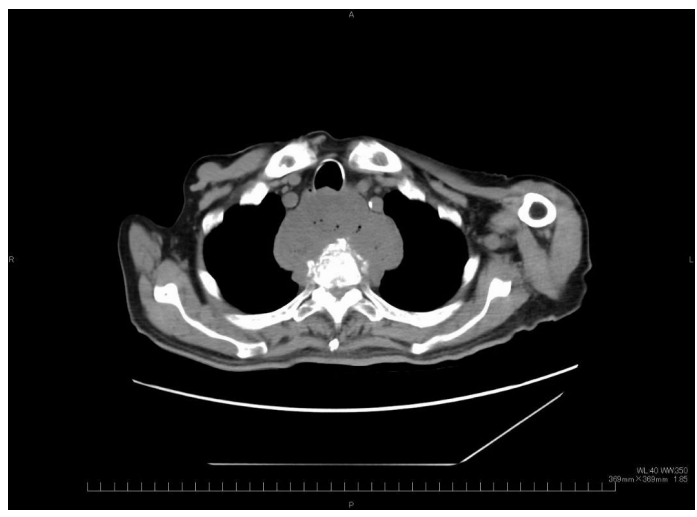

Figure 1 CT on admission.

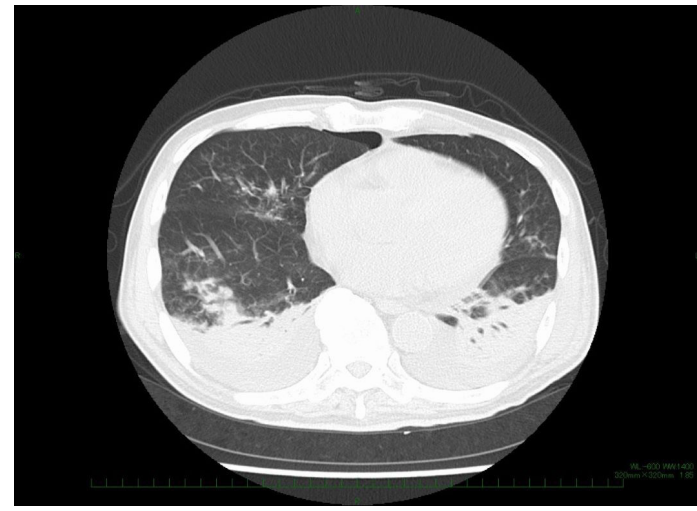

Figure 2 CT on admission suggesting right pneumothorax.

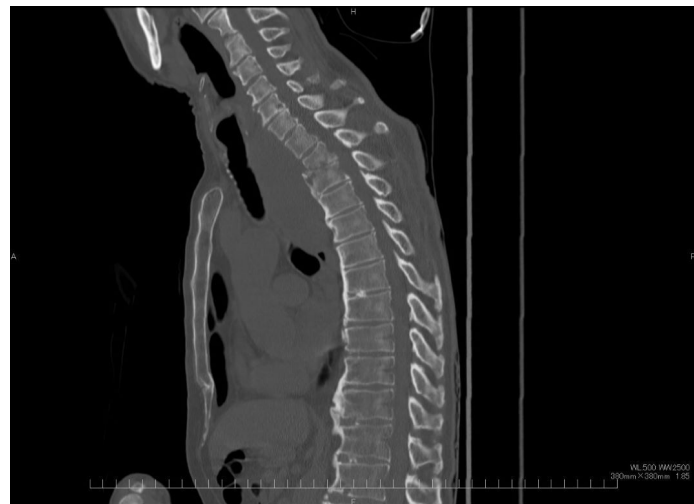

Figure $3 \mathrm{CT}$ on admission showing T2/3 spine destruction.

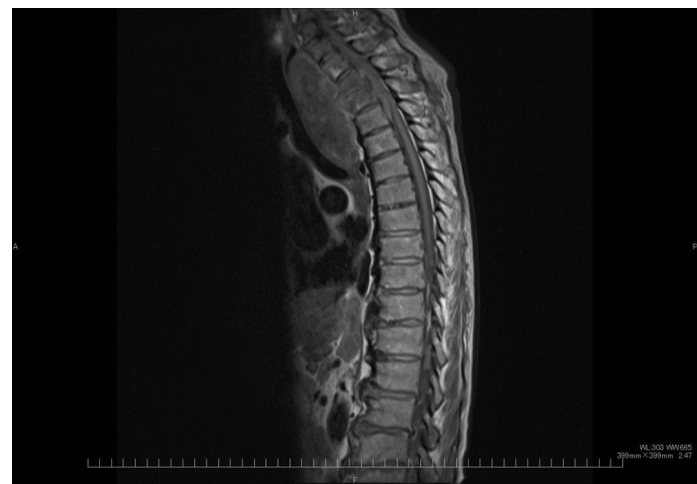

Figure $4 \mathrm{MRI}$ on admission showing T1W1.

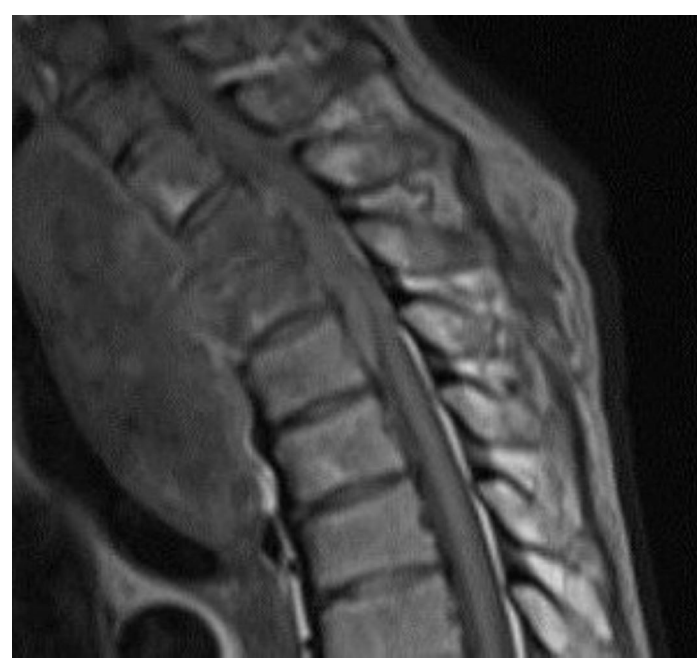

Figure 5 MRI on admission suggesting epidural abscess. 


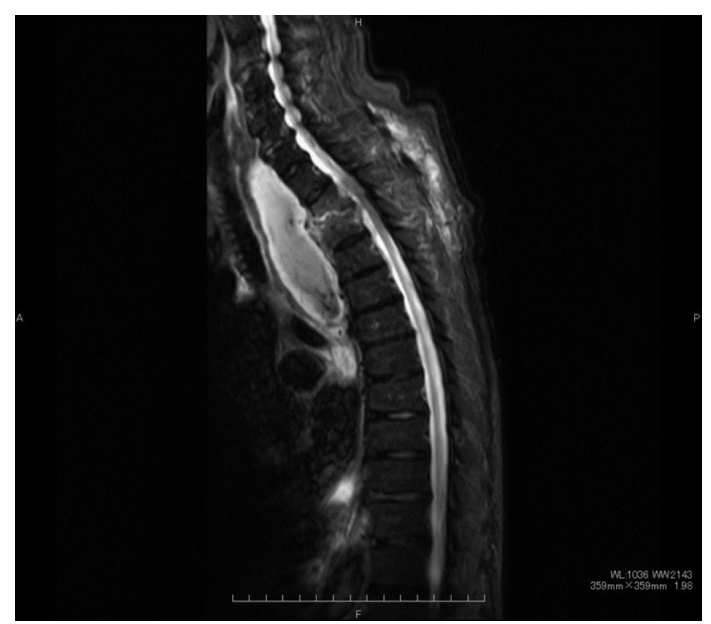

Figure 6 MRI on admission showing short T1 inversion recovery.

might exacerbate spinal instability. After a course of antibiotic therapy, he was transferred to another hospital for rehabilitation.

The aetiology of infection was not clear, but the preceding trauma was thought to be strongly associated. Osteomyelitis is known to follow a contiguous spread if untreated. Anterior contiguous spread can lead to retropharyngeal, mediastinal, retroperitoneal or psoas abscesses. In this case, it extended to the mediastinum and lung, causing abscesses and pneumothorax.

Epidural space is anatomically close to the pleural space. About one-third of cases of epidural abscesses arise through contiguous spread from adjacent spaces, including pleural spaces. ${ }^{1}$ Notably, a case report described an epidural empyema extending from a pleural empyema. ${ }^{2}$ This case also highlights the anatomical relationship between the epidural and pleural spaces.

\section{Learning points}

- Osteomyelitis should be treated early, as it can extend to adjacent tissues or organs.

- Tumours in the posterior mediastinum may be caused by vertebral osteomyelitis.

- Infection can spread between the spinal column, epidural space and pleural space.

Acknowledgements We would like to thank Editage (www.editage.com) for English language editing.

Contributors TN and KS were involved in discussion and provided treatment to the patient. TN collected the data and wrote the manuscript. HS advised about image selection for disease understanding. KS and TY reviewed and revised the manuscript. All authors read and approved the final manuscript.

Funding The authors have not declared a specific grant for this research from any funding agency in the public, commercial or not-for-profit sectors.

Competing interests None declared.

Patient consent for publication Obtained.

Provenance and peer review Not commissioned; externally peer reviewed.

Open access This is an open access article distributed in accordance with the Creative Commons Attribution Non Commercial (CC BY-NC 4.0) license, which permits others to distribute, remix, adapt, build upon this work non-commercially, and license their derivative works on different terms, provided the original work is properly cited and the use is non-commercial. See: http://creativecommons.org/ licenses/by-nc/4.0/.

\section{REFERENCES}

1 Darouiche RO. Spinal epidural abscess. N Engl J Med 2006;355:2012-20.

2 Torrealba Acosta G, Josephy Hernández S, Castro Ulloa G, et al. Spinal epidural empyema extending from a pleural empyema: case description and anatomical overview. BMJ Case Rep 2017;2017:1-3.

Copyright 2020 BMJ Publishing Group. All rights reserved. For permission to reuse any of this content visit

https://www.bmj.com/company/products-services/rights-and-licensing/permissions/

BMJ Case Report Fellows may re-use this article for personal use and teaching without any further permission.

Become a Fellow of BMJ Case Reports today and you can:

- Submit as many cases as you like

Enjoy fast sympathetic peer review and rapid publication of accepted articles

- Access all the published articles

Re-use any of the published material for personal use and teaching without further permission

Customer Service

If you have any further queries about your subscription, please contact our customer services team on +44 (0) 2071111105 or via email at support@bmj.com.

Visit casereports.bmj.com for more articles like this and to become a Fellow 